Gut and Liver, Vol. 11, No. 3, May 2017, pp. 349-357

REVIEW

\title{
Functional Dyspepsia: Advances in Diagnosis and Therapy
}

\author{
Nicholas J. Talley \\ Faculty of Health and Medicine, University of Newcastle and Hunter Medical Research Institute, Newcastle, NSW, Australia
}

Functional dyspepsia (FD) is a common but under-recognized syndrome comprising bothersome recurrent postprandial fullness, early satiety, or epigastric pain/burning. Epidemiologically, there are two clinically distinct FD syndromes (although these often overlap clinically): postprandial distress syndrome (PDS; comprising early satiety or meal-related fullness) and epigastric pain syndrome. Symptoms of gastroesophageal reflux disease overlap with FD more than expected by chance; a subset has pathological acid reflux. The pretest probability of FD in a patient who presents with classical FD symptoms and no alarm features is high, approximately 0.7. Coexistent heartburn should not lead to the exclusion of FD as a diagnosis. One of the most exciting observations in FD has been the consistent finding of increased duodenal eosinophilia, notably in PDS. Small bowel homing T cells, signaling intestinal inflammation, and increased cytokines have been detected in the circulation, and elevated tumor necrosis factor- $\alpha$ levels have been significantly correlated with increased anxiety. Postinfectious gastroenteritis is a risk factor for FD. Therapeutic options remain limited and provide only symptomatic benefit in most cases. Only one therapy is known to change the natural history of FD-Helicobacter pylori eradication. Treatment of duodenal eosinophilia is under investigation. (Gut Liver 2017;11:349-357)

Key Words: Functional dyspepsia; Epidemiology

\section{INTRODUCTION}

Functional gastrointestinal disorders (FGIDs) are common unexplained gastrointestinal (GI) symptom complexes that are thought to arise from different regions of the GI tract, and the two most recognized disorders are functional dyspepsia (FD) and the irritable bowel syndrome (IBS). FD is a clinical syndrome comprising chronic symptoms arising from the gas- troduodenal region. ${ }^{1}$ According to the Rome criteria, based on expert consensus, the prototypical symptoms are bothersome recurrent postprandial fullness, inability to finish a normal sized meal (early satiety), epigastric pain or epigastric burning in the setting of a normal upper endoscopy. ${ }^{2}$ However, many patients with FD also experience other troublesome symptoms including nausea, bloating, belching, and heartburn.

FD comprises two clinical syndromes which in clinical practice can overlap. Postprandial distress syndrome (PDS) is always meal related and refers to bothersome and frequent early satiety or postprandial fullness. These meal related symptoms are more common than heartburn and are reported by over $40 \%$ of the U.S. general population. ${ }^{3}$ A less common FD syndrome is epigastric pain syndrome (EPS) where patients present with recurrent and bothersome epigastric pain or less commonly epigastric burning. ${ }^{1}$

\section{EPIDEMIOLOGY}

In 100 population-based studies comprising over 312,000 subjects, the pooled prevalence of uninvestigated dyspepsia was $21 \%$ (95\% confidence interval, $18 \%$ to $24 \%$ ); the risk of dyspepsia was increased in females and those with Helicobacter pylori infection, smokers, and nonsteroidal anti-inflammatory drug users. ${ }^{4}$ Over 75\% with dyspepsia postinvestigation including esophagogastroduodenoscopy (EGD) will have no obvious structural explanation and based on current consensus are appropriately labelled as having FD. The most frequent finding of sometimes questionable significance is esophagitis (13\%) followed by peptic ulcer (8\%); in a meta-analysis of over 5,000 subjects endoscoped, only peptic ulcer was significantly associated with dyspepsia with a 2 -fold increased risk. ${ }^{5}$

In Olmsted County in the United States, evidence has emerged that FD is underdiagnosed in clinical practice; only $12.5 \%$ with FD symptoms received an FD diagnosis. ${ }^{6}$ The data suggest pa-

Correspondence to: Nicholas J. Talley

The Hunter Medical Research Institute, University of Newcastle, Kookaburra Circuit, Newcastle, NSW 2258, Australia

Tel: +61-249215855, Fax: +61-240420034, E-mail: nicholas.talley@newcastle.edu.au

Received on January 28, 2016. Accepted on May 19, 2016. Published online February 21, 2017

pISSN 1976-2283 eISSN 2005-1212 https://doi.org/10.5009/gnl16055

@. This is an Open Access article distributed under the terms of the Creative Commons Attribution Non-Commercial License (http://creativecommons.org/licenses/by-nc/4.0) which permits unrestricted non-commercial use, distribution, and reproduction in any medium, provided the original work is properly cited. 
tients with FD symptoms are more likely to be given the label gastroesophageal reflux disease (GERD) even if acid suppression therapy is unsuccessful. ${ }^{6}$

In FD, an increased risk of atopic diseases most notably asthma has been observed in a general practice database in the United Kingdom. ${ }^{7}$ Atopy may explain the finding of increased upper intestinal eosinophilia in FD, first reported in adults by Talley et al. ${ }^{8}$ Further, an increased risk of autoimmune disease has now been observed based on an extensive analysis of over 23,000 patients and controls from the U.K. general practice database; rheumatological disease in particular was increased. ${ }^{9}$

FD impacts on quality of life and impaired quality of life is associated with symptom severity and comorbid depression. ${ }^{10,11}$ The direct and indirect costs of FD because it is a highly prevalent and chronic condition are enormous. Extrapolating data on FD patients to the U.S. population, it has been calculated in 2009 the costs of FD were $\$ 18.4$ billion, ${ }^{12}$ and other independent data support these high cost figures. ${ }^{13,14}$ However, there is no mortality associated with dyspepsia symptoms in the general population indicating FD once diagnosed is a benign disorder and repeat EGD usually unhelpful. ${ }^{15}$

\section{DIAGNOSIS}

The diagnosis of FD remains one of exclusion as EGD is required to exclude peptic ulceration, esophagitis and malignancy. ${ }^{16}$ The Rome III criteria in terms of distinguishing FD from structural diseases such as peptic ulceration remain no better than previous Rome definitions, with a diagnostic sensitivity of $61 \%$ and a specificity of $69 \%$, both suboptimal. ${ }^{17}$ The pretest probability of FD in the patient who presents with classical dyspepsia (fullness, satiety, or epigastric pain) and no alarm features however is high, around 0.7 and therefore a provisional diagnosis in clinical practice can be considered in selected cases. Arguably the complaint that is the strongest indicator of FD is early satiety, a very distinctive symptom now linked to a specific duodenal pathology as discussed below. ${ }^{8}$ Many patients with FD present with overlapping symptoms of PDS and EPS although in population-based studies PDS and EPS separate out more clearly. ${ }^{18,19}$

\section{Meal testing}

Meal induced symptoms are an important and increasingly recognized feature of FD. In a landmark study, a solid test meal was ingested by patients with FD who either self-reported they had meal induced symptoms such as fullness or bloating, or reported their symptoms were not meal induced. However, remarkably most subjects despite their recollection had symptoms after the meal as recorded by diary every 15 minutes for 240 minutes, and these symptoms were clearly increased compared with healthy controls. ${ }^{20}$ Interestingly, those who self-reported they had meal induced symptoms generally developed symptoms early (within 15 minutes) after ingestion and fullness and bloating predominated, while those who self-reported no meal relationship usually had delayed postprandial symptom induction and pain or burning predominated. ${ }^{20}$

An objective test in FD that assesses meal related symptoms is the nutrient test meal. A standard approach is after an 8-hour fast, provide $200 \mathrm{~mL}$ of a standardized enteral feeding solution (e.g., Ensure) every 5 minutes up to a cumulative volume of $800 \mathrm{~mL}$; following each $200 \mathrm{~mL}$ drink, five key symptoms are assessed (fullness, abdominal pain, retrosternal/abdominal burning, nausea, and regurgitation) using a standardized instrument on visual analogue scales (0 to 100), and the cumulative symptom score across all symptoms calculated. ${ }^{21,22}$ The findings correlate with gastric motor and sensory dysfunction and are an indirect measure of gastric accommodation, but are decreased in old age. ${ }^{21,22}$ However, the diagnostic utility of a nutrient test meal has not been investigated in the clinical setting and it remains an investigational tool. Irregular meal ingestion and rapid eating behavior are risk factors for FD perhaps because gastroduodenal dysfunction limits normal eating and may even promote weight loss. ${ }^{23,24}$

\section{Differentiating FD from gastroparesis}

A particularly confusing issue yet to be resolved is how to distinguish gastroparesis from FD. The fundamental problem is slow gastric emptying occurs in 25\% with FD but there is no clear-cut symptom complex associated. ${ }^{25}$ The U.S. gastroparesis consortium definition that has been widely applied, namely that gastroparesis refers to upper GI symptoms and slow gastric emptying is arguably unhelpful, as symptom correlation with slow emptying in this broader patient cohort is modest to poor, slow gastric emptying on repeat testing is not a very consistent finding, and accelerating gastric emptying with prokinetics fails to accurately parallel symptom response. ${ }^{26}$ If gastroparesis is more strictly defined as very slow gastric emptying ( 3 or more standard deviations from normal), then vomiting and weight loss may be more predictably associated and the true albeit rare syndrome apparent. ${ }^{27}$

\section{Confusion with GERD}

Symptoms of GERD overlap with FD as otherwise defined by Rome III more than expected by chance; a subset of these overlap cases have pathological acid reflux. ${ }^{28}$ Recent data suggest gastric disaccommodation increases the number of transient lower esophageal relaxations. ${ }^{29}$ As a subset with FD (up to 40\%) also have a failure of gastric accommodation, this may account for the overlap of FD with GERD, and further suggests the strict exclusion of all heartburn from the definition of FD introduces substantial selection bias. 


\section{Confusion with other FGIDs}

In clinical practice, other symptoms may accompany dyspepsia and if predominant can point to alternative diagnoses. In particular, frequent vomiting is a very unusual symptom in the dyspepsia symptom complex and in addition to considering gastroparesis and other rarer causes such as brain stem disease, drugs including cannabis (that can induce cyclic vomiting and sometimes compulsive bathing behavior) need consideration. ${ }^{30}$ Unrelenting abdominal pain is not a feature of FD and other possibilities such as functional abdominal pain syndrome or narcotic bowel syndrome should be considered. ${ }^{31,32}$

\section{PATHOGENESIS}

\section{Familial aggregation and genes}

Familial aggregation of abdominal pain has been reported in FD implying either genes or early life factors must be important in the pathogenesis. ${ }^{33}$ Genetic factors likely play a role in disease pathogenesis but data are limited. Evidence implicates disturbed signal transduction in FD with a number of studies linking the polymorphism GNB3 C825T to FD. Both the CC and TT variant have been associated with FD in different populations. ${ }^{34-36}$ The relevance of other genetic variants is less certain and contradictory in the literature, and large robust studies are needed. ${ }^{37}$

\section{Psychological distress}

New evidence suggests anxiety often precedes the onset of FD. Among 703 community subjects who completed questionnaires and an upper endoscopy at entry, 10 years later the risk of FD developing was nearly 8-fold increased in those with higher anxiety levels; depression on the other hand was not a risk factor. ${ }^{38}$ Further, the risk of FD in those with anxiety was limited to PDS and not EPS. ${ }^{38}$ Other data suggest one-third of people who develop an FGID like FD have symptoms that begin in the gut then new onset psychological distress develops; half to two-thirds start with anxiety and then develop gut symptoms suggesting a central rather than peripheral pathogenesis. ${ }^{39}$

Sleep dysfunction and multiple somatic complaints are also more common in FD in community based studies, ${ }^{33}$ but increased somatic complaints may be as frequent in those with a definite structural explanation for their dyspepsia as in cases with FD, suggesting FD is not simply a somatization disorder. ${ }^{40}$ A history of abuse is more frequent in FD but abuse does not appear to be an independent risk factor once depression and other psychological factors are controlled for in the analyses. ${ }^{41}$

\section{Gastroduodenal motor and sensory dysfunction}

Gastric emptying is slow in 25\% of patients with FD, but symptoms fail to correlate with delayed gastric emptying in this syndrome; in a very small number, rapid gastric emptying has also been documented. ${ }^{42}$ While gastric emptying is a biomarker of a subset with FD, it does not appear to explain the reduced quality of life documented in such patients. ${ }^{43}$ Gastric hypersensitivity and impaired gastric accommodation also occur in subsets of patients, and these abnormalities can overlap. ${ }^{44}$ Recent observations suggest patients with PDS and impaired gastric accommodation are more likely to have anxiety too. ${ }^{45}$

Perturbations of duodenal function have also been documented in acid infusion experiments implicating duodenal dysfunction in FD. Notably, in health acid can sensitize volunteers to the development of dyspepsia symptoms, and impair antral contractility while increasing upper intestinal contractility. ${ }^{46}$ Acid instilled into the duodenum also relaxes the stomach identifying a duodenum-gastric excitatory reflex pathway that is partly inhibited by local anaesthetic. ${ }^{47}$

Further, postprandial gut hormone response may be abnormal in FD. Thus raised ghrelin levels after breakfast has been observed in FD compared with healthy controls. ${ }^{48}$ Excessive local release of cholecystokinin (CCK) after duodenal lipid ingestion has also been observed and independently confirmed, further implicating the duodenum in the pathogenesis of FD; CCK release may stimulate vagal afferents that increase gut-brain cross talking. ${ }^{49-51}$

\section{Duodenal eosinophilia}

One of the most exciting observations in FD has been the consistent finding of duodenal eosinophilia in many cases with PDS around the world, following the first report in adults by Talley et al. ${ }^{8,52-55}$ The normal cutoff may vary geographically but more than 22 eosinophils in 5 high power fields is generally considered abnormal; otherwise biopsies look normal and the eosinophilia will not usually be detected unless counting is performed (Fig. 1). In Belgium, elegant experimental work has confirmed duodenal eosinophilia and also observed increased

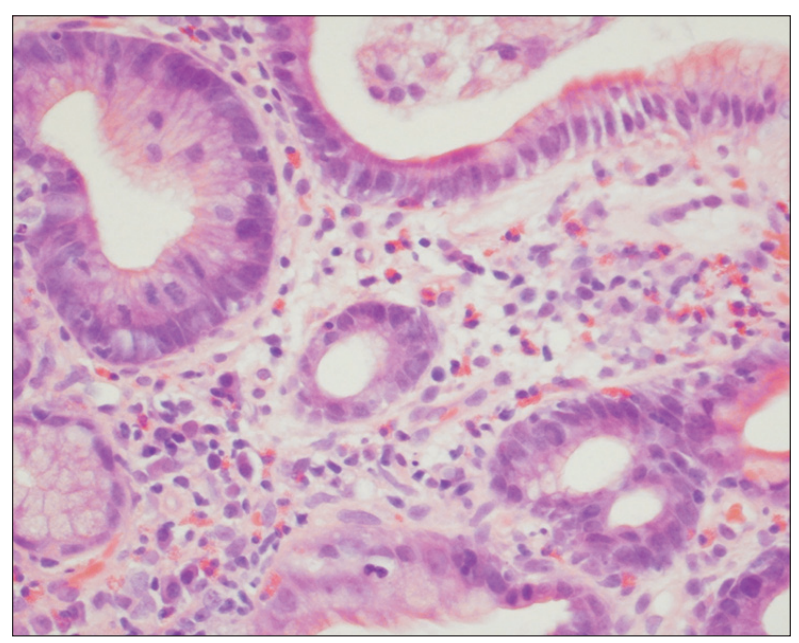

Fig. 1. Increased duodenal eosinophils in a patient with functional dyspepsia $(\mathrm{H} \& \mathrm{E}, \times 40)$ (with permission from Walker MM and Talley NJ, 2016). 
duodenal mast cells. ${ }^{56}$ Notably the patient cohort in nine of the 15 cases had overlapping FD and IBS which may account for the increased mast cells, as Walker et al. ${ }^{56}$ found duodenal mast cells were characteristic of IBS but not pure (nonoverlapping) FD.

Further, submucosal neuronal structural and functional changes have been identified in the duodenum in FD linked to the duodenal eosinophilia and mast cell infiltration. ${ }^{57,58}$ In an Australian endoscopic study, smoking was a risk factor for duodenal eosinophilia ${ }^{53}$ and similar results were reported in a population-based study from Iran. ${ }^{59}$ In further elegant work from Australia, small bowel homing $\mathrm{T}$ cells, signaling intestinal inflammation, and increased cytokines have been detected in the circulation, and elevated tumor necrosis factor- $\alpha$ levels have been significantly correlated with increased anxiety. ${ }^{60}$ The findings suggest immune dysregulation is a key feature of a large subset with FD and a better understanding of the immunology holds out hope for novel approaches to therapy. ${ }^{61}$

What may induce duodenal eosinophilia and FD? Recent epidemiological data from Australia suggest exposure to herbivore pets (e.g., horses) but not carnivores (e.g., dogs) is associated with an increased risk of FD. ${ }^{62}$ Horses are heavily infested with parasites which can induce eosinophilic inflammation in the human gut, so this hypothesis makes sense albeit it needs confirmation. ${ }^{62}$ Food allergy or intolerance, particularly wheat exposure has been hypothesized to be important in FD but firm data are needed. ${ }^{63}$ Antibiotics and postinfectious gastroenteritis are risk factors perhaps through altering the microbiome. ${ }^{64,65}$

\section{Postinfectious FD}

FD is now established to develop after acute bacterial, protozoal or viral gastroenteritis, with a 2.5 -fold increased risk. ${ }^{66}$ Alternatively, post-gastroenteritis IBS or an overlap syndrome comprising FD and IBS can develop, implying a similar pathogenesis for the postinfectious subset. ${ }^{66,67}$ Risk factors for postinfectious FD include smoking, ${ }^{66}$ and smoking is a risk factor for duodenal eosinophilia. ${ }^{53}$ Japanese investigators have noted increased duodenal eosinophils in postinfectious $\mathrm{FD},{ }^{68}$ and postinfection early satiety and gastric disaccommodation are significantly more likely ${ }^{69}$ suggesting duodenal eosinophilia may occur after gut infection and this is linked to proximal gastric dysfunction. After giardia infection among cases with postinfectious IBS and postprandial dyspepsia symptoms, increased duodenal CCK in the mucosa has been reported perhaps explaining the increased circulating CCK levels observed by others as described above. ${ }^{70}$ Baseline psychological distress is also a risk factor for postinfectious FD. ${ }^{68}$

One unifying hypothesis linking duodenal inflammation and postinfectious FGID is the symptom phenotype depends on the distribution of the postinfectious inflammation; if limited to the proximal intestine FD can result but if more widespread the overlap of FD and IBS may eventuate. ${ }^{71}$

\section{TREATMENT}

A firm diagnosis followed by explanation and reassurance are key elements of the therapeutic equation and may help maximize the placebo response if therapy is prescribed. Those with fluctuating symptoms are more likely to respond to placebo. ${ }^{72}$ Simple dietary advice may help some patients although randomized controlled trials are lacking. In particular, eating small meals that are low fat is a reasonable starting point. ${ }^{73}$ Multiple drug classes have been trialed to treat FD but therapeutic options remain limited and provide in most cases only symptomatic benefit (Table 1). Only one therapy is known to change the natural history of FD and that is $H$. pylori eradication therapy. ${ }^{74-76}$

\section{H. pylori identification and treatment}

Randomized controlled trials have compared eradication therapy with either placebo or acid suppression. While some trials have failed to observe a clear difference from placebo this is likely related to them being underpowered ${ }^{77}$ as others have shown a clear benefit. ${ }^{78}$ A meta-analysis concluded $H$. pylori eradication therapy was superior to either placebo or antisecretory therapy with a number needed to treat of $17 .^{79}$ The Kyoto consensus conference concluded if a patient with FD and $H$. pylori infection responds to eradication therapy and the treatment response persists, then the correct diagnosis is $H$. pylori associated dyspepsia; the majority who fail to obtain symptom relief despite successful eradication therapy have FD until proven otherwise. ${ }^{80}$ However, no trial has randomized both $H$. pylori positive and negative patients to eradication therapy or placebo to test the alternative hypothesis that antibiotic therapy is the reason symptoms settle through alteration of the gastroduodenal microbiome. ${ }^{81}$

\section{Acid suppression}

Proton pump inhibitor (PPI) therapy has become first line treatment for $\mathrm{FD}^{82}$ but it is important to recognize the majority of patients will fail this approach even if high dose PPI is prescribed. ${ }^{79}$ The best response is seen in those with epigastric pain. ${ }^{83}$ Further, closer study of the meta-analysis data reveals $\mathrm{H}_{2}$ blockade may be more efficacious than PPI although the $\mathrm{H}_{2}$ blocker data are admittedly more heterogeneous. ${ }^{79}$ If true, the benefit of $\mathrm{H}_{2}$ blockade cannot be explained by acid suppression alone. It is of interest mast cell infiltration may lead to histamine release and one could speculate this is a potential reason for any efficacy. Combining a $\mathrm{H}_{1}$ with a $\mathrm{H}_{2}$ blocker anecdotally may reduce dyspepsia symptoms and we have seen success in adults. ${ }^{84}$ PPIs do inhibit eotaxin and therefore may also suppress duodenal eosinophils if present. ${ }^{85}$

\section{Prokinetic}

Prokinetic therapy overall is superior to placebo based on me- 
Table 1. Pharmacological Treatment Options for Functional Dyspepsia Based on Double-Blind Randomized Placebo-Controlled Trials

\begin{tabular}{|c|c|}
\hline Level of evidence & Comment \\
\hline Helicobacter pylori eradication (level 1) & First line therapy in infected \\
\hline \multicolumn{2}{|l|}{ Acid suppression (level 1) } \\
\hline Proton pump inhibitors & First line therapy especially for epigastric pain \\
\hline \multicolumn{2}{|l|}{$\mathrm{H}_{2}$ receptor antagonists } \\
\hline \multicolumn{2}{|l|}{ Prokinetic (level 1-2) } \\
\hline Cisapride & Cisapride withdrawn \\
\hline Acotiamide & Available in Japan \\
\hline Itopride & Mixed data \\
\hline \multicolumn{2}{|l|}{ Centrally acting drugs (level 1-2) } \\
\hline Tricyclic low dose (level 1) & Epigastric pain improved \\
\hline Mirtazapine (level 2) & Efficacy not established \\
\hline Buspirone (level 2) & Postprandial distress syndrome improved \\
\hline \multicolumn{2}{|l|}{ Miscellaneous therapy } \\
\hline Iberogast (level 2) & Relaxes the gastric fundus \\
\hline Montelukast & One small pediatric trial \\
\hline \multicolumn{2}{|l|}{ Not efficacious } \\
\hline \multicolumn{2}{|l|}{ Selective serotonin reuptake inhibitors } \\
\hline \multicolumn{2}{|l|}{ Selective norepinephrine reuptake inhibitors } \\
\hline \multicolumn{2}{|l|}{ Antacids } \\
\hline \multicolumn{2}{|l|}{ Sucralfate } \\
\hline \multicolumn{2}{|l|}{ Bismuth } \\
\hline Mosapride & \\
\hline
\end{tabular}

ta-analysis data of randomized controlled trials but the results are largely driven by cisapride that has limited to no availability and was withdrawn because of concern over QT prolongation and the risk of sudden death. ${ }^{79}$ Cisapride, a 5HT4 agonist does relax the gastric fundus plus it has 5HT3 antagonist actions that may improve nausea.

Very limited and poor quality evidence exists for any benefit of metoclopramide in FD and side effects including tardive dyskinesia limits this drugs use. Domperidone, a peripherally acting dopamine 2 antagonist, is an alternative but again the evidence of efficacy is limited and it can also prolong the QT interval so its use must be judiciously considered. ${ }^{86}$

Itopride is of uncertain efficacy following two major trials that were essentially negative ${ }^{87}$ although a meta-analysis of nine trials supported its therapeutic application providing evidence in support of a landmark trial published in the New England Journal of Medicine. ${ }^{88,89}$ The inconsistency of the results may reflect patient selection issues; the pivotal negative phase III trials had very strict entry criteria excluding any GERD but other positive studies did not apply the same approach and allowed reflux symptoms. As there is accumulating evidence reflux symptoms are part of the spectrum of FD, the strict exclusion of heartburn is probably inappropriate. Mosapride does relax the gastric fundus $^{90}$ but in a meta-analysis mosapride was not superior to pla- cebo in FD and the drug cannot at this time be recommended. ${ }^{91}$ Acotiamide, an acetylcholinesterase inhibitor that increases acetylcholine release in the enteric nervous system, is efficacious based on a meta-analysis in a dose of $100 \mathrm{mg}$ three times daily but only for PDS, not EPS; it is commercially available in Japan and trials in Europe are progressing. ${ }^{92,93}$

Buspirone, an antianxiety agent, relaxes the gastric fundus through its action on 5HT1 receptors, and in a randomized cross-over clinical trial reduced PDS symptoms over placebo at a dose of $10 \mathrm{mg}$ three times daily over 4 weeks. ${ }^{94}$

\section{Antidepressants}

The largest randomized controlled trial to date included 292 patients who were randomized to the low dose tricyclic amitriptyline ( $25 \mathrm{mg}$ for 2 weeks then $50 \mathrm{mg}$ for 10 weeks), escitalopram (a full dose selective serotonin reuptake inhibitor [SSRI] at $10 \mathrm{mg}$ for 12 weeks) or placebo. The tricyclic was efficacious for those with epigastric pain but was not of benefit in those with delayed gastric emptying. ${ }^{95}$ A meta-analysis of psychotropic agents concluded tricyclic antidepressants were superior to placebo but there remains a risk of side effects with this class of agents with the number needed to harm being seven. ${ }^{96}$ There was no benefit observed over placebo with the SSRIs or selective norepinephrine reuptake inhibitors. ${ }^{96}$ Antipsychotic class drugs 
were also superior to placebo. ${ }^{96}$ Mirtazapine is a tetracyclic antidepressant with antinausea properties. One trial suggested a trend towards symptom improvement compared with placebo in FD but the results were not definitive. ${ }^{97}$

\section{Miscellaneous therapies}

Montelukast, the antiasthma drug and eosinophil stabilizer, was superior to placebo in a small randomized controlled trial in pediatric patients with FD but no adult data are available. ${ }^{98}$ Iberogast (STW5) is a nine herb combination that relaxes the gastric fundus through unknown mechanisms. ${ }^{99}$ The product has modest efficacy in FD based on randomized trials although methodological issues limit interpretability of the data. ${ }^{100}$

Acupuncture studies have suggested a possible benefit but the risk of bias remains high in the available studies and more convincing evidence is needed to exclude a placebo effect. ${ }^{101}$ In difficult or resistant cases, combination therapy including psychological and centrally acting drug treatment should be considered as the outcomes are likely improved based on limited randomized trial evidence. ${ }^{102}$

\section{PROGNOSIS}

In the general population, two studies have observed dyspepsia is not associated with any reduction of life expectancy confirming FD is a benign diagnosis. ${ }^{15,103}$ Ten years follow-up data from a population-based endoscopy study has provided a clearer picture of the prognosis of FD; only a minority resolve (20\%), others develop a new FGID with or without GERD (37\%) and the remainder (43\%) have persistent dyspepsia. ${ }^{38}$

\section{CONCLUSIONS}

FD is a common disorder; up to $40 \%$ appear to have structural alterations in the duodenum including increased duodenal permeability, duodenal eosinophilia and neural alterations, suggesting the term functional is a misnomer. GERD and FD may in some cases share a similar pathogenesis and separating GERD from FD is largely artificial. FD symptoms impair quality of life and treatment is indicated if simple measures such as reassurance and dietary restrictions fail. Medical therapy remains largely symptom driven although in patients with $H$. pylori infection there is the hope of symptom cure in a small minority with eradication therapy. The observation of duodenal eosinophilia in a substantial proportion with FD has opened up new diagnostic and therapeutic possibilities.

\section{CONFLICTS OF INTEREST}

Dr Talley is funded by the National Health and Medical Reearch Council of Australia. He has received grant support from Commonwealth Diagnostic Laboratories, Prometheus, GI Thera- pies, Janssen, Abbott, Pfizer and Salix, and consulted for Allergan, Yuhan, Adelphi Values and GI Therapies.

\section{REFERENCES}

1. Talley NJ, Ford AC. Functional dyspepsia. N Engl J Med 2015; 373:1853-1863.

2. Tack J, Talley NJ, Camilleri M, et al. Functional gastroduodenal disorders. Gastroenterology 2006;130:1466-1479.

3. Camilleri M, Dubois D, Coulie B, et al. Prevalence and socioeconomic impact of upper gastrointestinal disorders in the United States: results of the US Upper Gastrointestinal Study. Clin Gastroenterol Hepatol 2005;3:543-552.

4. Ford AC, Marwaha A, Sood R, Moayyedi P. Global prevalence of, and risk factors for, uninvestigated dyspepsia: a meta-analysis. Gut 2015;64:1049-1057.

5. Ford AC, Marwaha A, Lim A, Moayyedi P. What is the prevalence of clinically significant endoscopic findings in subjects with dyspepsia? Systematic review and meta-analysis. Clin Gastroenterol Hepatol 2010;8:830-837.e2.

6. Pleyer C, Bittner H, Locke GR 3rd, et al. Overdiagnosis of gastroesophageal reflux disease and underdiagnosis of functional dyspepsia in a USA community. Neurogastroenterol Motil 2014;26: 1163-1171.

7. Jones MP, Walker MM, Ford AC, Talley NJ. The overlap of atopy and functional gastrointestinal disorders among 23,471 patients in primary care. Aliment Pharmacol Ther 2014;40:382-391.

8. Talley NJ, Walker MM, Aro P, et al. Non-ulcer dyspepsia and duodenal eosinophilia: an adult endoscopic population-based casecontrol study. Clin Gastroenterol Hepatol 2007;5:1175-1183.

9. Ford AC, Talley NJ, Walker MM, Jones MP. Increased prevalence of autoimmune diseases in functional gastrointestinal disorders: case-control study of 23471 primary care patients. Aliment Pharmacol Ther 2014;40:827-834.

10. Aro P, Talley NJ, Agréus L, et al. Functional dyspepsia impairs quality of life in the adult population. Aliment Pharmacol Ther 2011;33:1215-1224.

11. Haag S, Senf W, Häuser W, et al. Impairment of health-related quality of life in functional dyspepsia and chronic liver disease: the influence of depression and anxiety. Aliment Pharmacol Ther 2008;27:561-571.

12. Lacy BE, Weiser KT, Kennedy AT, Crowell MD, Talley NJ. Functional dyspepsia: the economic impact to patients. Aliment Pharmacol Ther 2013;38:170-177.

13. Brook RA, Kleinman NL, Choung RS, Melkonian AK, Smeeding JE, Talley NJ. Functional dyspepsia impacts absenteeism and direct and indirect costs. Clin Gastroenterol Hepatol 2010;8:498503.

14. Brook RA, Kleinman NL, Choung RS, Smeeding JE, Talley NJ. Excess comorbidity prevalence and cost associated with functional dyspepsia in an employed population. Dig Dis Sci 2012;57:109118. 
15. Chang JY, Locke GR 3rd, McNally MA, et al. Impact of functional gastrointestinal disorders on survival in the community. Am J Gastroenterol 2010;105:822-832.

16. Moayyedi P, Talley NJ, Fennerty MB, Vakil N. Can the clinical history distinguish between organic and functional dyspepsia? JAMA 2006;295:1566-1576.

17. Ford AC, Bercik P, Morgan DG, Bolino C, Pintos-Sanchez MI, Moayyedi P. The Rome III criteria for the diagnosis of functional dyspepsia in secondary care are not superior to previous definitions. Gastroenterology 2014;146:932-940.

18. Vakil N, Halling K, Ohlsson L, Wernersson B. Symptom overlap between postprandial distress and epigastric pain syndromes of the Rome III dyspepsia classification. Am J Gastroenterol 2013;108:767-774.

19. Tack J, Talley NJ. Functional dyspepsia: symptoms, definitions and validity of the Rome III criteria. Nat Rev Gastroenterol Hepatol 2013;10:134-141.

20. Bisschops R, Karamanolis G, Arts J, et al. Relationship between symptoms and ingestion of a meal in functional dyspepsia. Gut 2008;57:1495-1503.

21. Gururatsakul M, Holloway RH, Bellon M, Bartholomeusz D, Talley NJ, Holtmann GJ. Complicated and uncomplicated peptic ulcer disease: altered symptom response to a nutrient challenge linked to gastric motor dysfunction. Digestion 2014;89:239-246.

22. Gururatsakul M, Holloway RH, Adam B, Liebregts T, Talley NJ, Holtmann GJ. The ageing gut: diminished symptom response to a standardized nutrient stimulus. Neurogastroenterol Motil 2010;22:246-e77.

23. Keshteli AH, Feizi A, Esmaillzadeh A, et al. Patterns of dietary behaviours identified by latent class analysis are associated with chronic uninvestigated dyspepsia. Br J Nutr 2015;113:803-812.

24. Jones MP, Talley NJ, Eslick GD, Dubois D, Tack J. Community subgroups in dyspepsia and their association with weight loss. Am J Gastroenterol 2008;103:2051-2060.

25. Talley NJ, Locke GR 3rd, Lahr BD, et al. Functional dyspepsia, delayed gastric emptying, and impaired quality of life. Gut 2006;55:933-939.

26. Stanghellini V, Tack J. Gastroparesis: separate entity or just a part of dyspepsia? Gut 2014;63:1972-1978.

27. Jung HK, Choung RS, Locke GR 3rd, et al. The incidence, prevalence, and outcomes of patients with gastroparesis in Olmsted County, Minnesota, from 1996 to 2006. Gastroenterology 2009;136:1225-1233.

28. Savarino E, Pohl D, Zentilin P, et al. Functional heartburn has more in common with functional dyspepsia than with nonerosive reflux disease. Gut 2009;58:1185-1191.

29. Pauwels A, Altan E, Tack J. The gastric accommodation response to meal intake determines the occurrence of transient lower esophageal sphincter relaxations and reflux events in patients with gastro-esophageal reflux disease. Neurogastroenterol Motil 2014:26:581-588.

30. Choung RS, Locke GR 3rd, Lee RM, Schleck CD, Zinsmeister AR,
Talley NJ. Cyclic vomiting syndrome and functional vomiting in adults: association with cannabinoid use in males. Neurogastroenterol Motil 2012;24:20-e1.

31. Choung RS, Locke GR, Schleck CD, Zinsmeister AR, Talley NJ. Associations between medication use and functional gastrointestinal disorders: a population-based study. Neurogastroenterol Motil 2013;25:413-e298.

32. Choung RS, Locke GR 3rd, Zinsmeister AR, Schleck CD, Talley NJ. Opioid bowel dysfunction and narcotic bowel syndrome: a population-based study. Am J Gastroenterol 2009;104:11991204.

33. Gathaiya N, Locke GR 3rd, Camilleri M, Schleck CD, Zinsmeister AR, Talley NJ. Novel associations with dyspepsia: a communitybased study of familial aggregation, sleep dysfunction and somatization. Neurogastroenterol Motil 2009;21:922-e69.

34. Holtmann G, Siffert W, Haag S, et al. G-protein beta 3 subunit 825 CC genotype is associated with unexplained (functional) dyspepsia. Gastroenterology 2004;126:971-979.

35. Shimpuku M, Futagami S, Kawagoe T, et al. G-protein beta3 subunit $825 \mathrm{CC}$ genotype is associated with postprandial distress syndrome with impaired gastric emptying and with the feeling of hunger in Japanese. Neurogastroenterol Motil 2011;23:10731080.

36. Singh R, Mittal B, Ghoshal UC. Functional dyspepsia is associated with GNbeta3 C825T and CCK-AR T/C polymorphism. Eur J Gastroenterol Hepatol 2016;28:226-232.

37. Kourikou A, Karamanolis GP, Dimitriadis GD, Triantafyllou K. Gene polymorphisms associated with functional dyspepsia. World J Gastroenterol 2015;21:7672-7682.

38. Aro P, Talley NJ, Johansson SE, Agréus L, Ronkainen J. Anxiety is linked to new-onset dyspepsia in the Swedish population: a 10-year follow-up study. Gastroenterology 2015;148:928-937.

39. Koloski NA, Jones M, Kalantar J, Weltman M, Zaguirre J, Talley NJ. The brain-gut pathway in functional gastrointestinal disorders is bidirectional: a 12-year prospective population-based study. Gut 2012;61:1284-1290.

40. Gracie DJ, Bercik P, Morgan DG, et al. No increase in prevalence of somatization in functional vs organic dyspepsia: a crosssectional survey. Neurogastroenterol Motil 2015;27:1024-1031.

41. Koloski NA, Talley NJ, Boyce PM. A history of abuse in community subjects with irritable bowel syndrome and functional dyspepsia: the role of other psychosocial variables. Digestion 2005;72:86-96.

42. Haag S, Talley NJ, Holtmann G. Symptom patterns in functional dyspepsia and irritable bowel syndrome: relationship to disturbances in gastric emptying and response to a nutrient challenge in consulters and non-consulters. Gut 2004;53:1445-1451.

43. Haag S, Senf W, Tagay $S$, et al. Is there any association between disturbed gastrointestinal visceromotor and sensory function and impaired quality of life in functional dyspepsia? Neurogastroenterol Motil 2010;22:262-e79.

44. Van Oudenhove L, Vandenberghe J, Geeraerts B, et al. Deter- 
minants of symptoms in functional dyspepsia: gastric sensorimotor function, psychosocial factors or somatisation? Gut 2008;57:1666-1673.

45. Ly HG, Weltens N, Tack J, Van Oudenhove L. Acute anxiety and anxiety disorders are associated with impaired gastric accommodation in patients with functional dyspepsia. Clin Gastroenterol Hepatol 2015;13:1584-1591.e3.

46. di Stefano M, Vos R, Vanuytsel T, Janssens J, Tack J. Prolonged duodenal acid perfusion and dyspeptic symptom occurrence in healthy volunteers. Neurogastroenterol Motil 2009;21:712-e40.

47. Vanuytsel T, Karamanolis G, Vos R, Van Oudenhove L, Farré $\mathrm{R}$, Tack J. Role of duodenal mucosal nerve endings in the acidinduced duodenogastric sensorimotor reflex: effect of benzocaine in healthy humans. Neurogastroenterol Motil 2013;25:e353-e361.

48. Kazemi M, Eshraghian A, Hamidpour L, Taghavi S. Changes in serum ghrelin level in relation to meal-time in patients with functional dyspepsia. United European Gastroenterol J 2015;3:11-16.

49. Pilichiewicz AN, Feltrin KL, Horowitz M, et al. Functional dyspepsia is associated with a greater symptomatic response to fat but not carbohydrate, increased fasting and postprandial CCK, and diminished PYY. Am J Gastroenterol 2008;103:2613-2623.

50. van Boxel OS, ter Linde JJ, Oors J, Otto B, et al. Functional dyspepsia patients have lower mucosal cholecystokinin concentrations in response to duodenal lipid. Eur J Gastroenterol Hepatol 2014;26:205-212.

51. Bharucha AE, Camilleri M, Burton DD, et al. Increased nutrient sensitivity and plasma concentrations of enteral hormones during duodenal nutrient infusion in functional dyspepsia. Am J Gastroenterol 2014;109:1910-1920.

52. Friesen CA, Schurman JV, Colombo JM, Abdel-Rahman SM. Eosinophils and mast cells as therapeutic targets in pediatric functional dyspepsia. World J Gastrointest Pharmacol Ther 2013;4:8696.

53. Walker MM, Aggarwal KR, Shim LS, et al. Duodenal eosinophilia and early satiety in functional dyspepsia: confirmation of a positive association in an Australian cohort. J Gastroenterol Hepatol 2014;29:474-479.

54. Nwokediuko SC, Ijoma UN, Obienu 0, Anigbo GE, Okafor O. High degree of duodenal inflammation in Nigerians with functional dyspepsia. Clin Exp Gastroenterol 2013;7:7-12.

55. Walker MM, Salehian SS, Murray CE, et al. Implications of eosinophilia in the normal duodenal biopsy: an association with allergy and functional dyspepsia. Aliment Pharmacol Ther 2010;31: 1229-1236.

56. Walker MM, Talley NJ, Prabhakar M, et al. Duodenal mastocytosis, eosinophilia and intraepithelial lymphocytosis as possible disease markers in the irritable bowel syndrome and functional dyspepsia. Aliment Pharmacol Ther 2009;29:765-773.

57. Vanheel H, Vicario M, Vanuytsel T, et al. Impaired duodenal mucosal integrity and low-grade inflammation in functional dyspepsia. Gut 2014;63:262-271.

58. Cirillo C, Bessissow T, Desmet AS, Vanheel H, Tack J, Vanden
Berghe P. Evidence for neuronal and structural changes in submucous ganglia of patients with functional dyspepsia. Am J Gastroenterol 2015;110:1205-1215.

59. Esmaillzadeh A, Keshteli AH, Tabesh M, Feizi A, Adibi P. Smoking status and prevalence of upper gastrointestinal disorders. Digestion 2014;89:282-290.

60. Liebregts T, Adam B, Bredack C, et al. Small bowel homing T cells are associated with symptoms and delayed gastric emptying in functional dyspepsia. Am J Gastroenterol 2011;106:1089-1098.

61. Keely S, Walker MM, Marks E, Talley NJ. Immune dysregulation in the functional gastrointestinal disorders. Eur J Clin Invest 2015;45:1350-1359.

62. Koloski NA, Jones M, Weltman M, et al. Identification of early environmental risk factors for irritable bowel syndrome and dyspepsia. Neurogastroenterol Motil 2015;27:1317-1325.

63. Boettcher E, Crowe SE. Dietary proteins and functional gastrointestinal disorders. Am J Gastroenterol 2013;108:728-736.

64. Paula H, Grover M, Halder SL, et al. Non-enteric infections, antibiotic use, and risk of development of functional gastrointestinal disorders. Neurogastroenterol Motil 2015;27:1580-1586.

65. Walker MM, Talley NJ. Review article: bacteria and pathogenesis of disease in the upper gastrointestinal tract: beyond the era of Helicobacter pylori. Aliment Pharmacol Ther 2014;39:767-779.

66. Futagami S, Itoh T, Sakamoto C. Systematic review with metaanalysis: post-infectious functional dyspepsia. Aliment Pharmacol Ther 2015;41:177-188.

67. Tuteja AK, Talley NJ, Gelman SS, et al. Development of functional diarrhea, constipation, irritable bowel syndrome, and dyspepsia during and after traveling outside the USA. Dig Dis Sci 2008;53: 271-276.

68. Futagami S, Shindo T, Kawagoe T, et al. Migration of eosinophils and CCR2-/CD68-double positive cells into the duodenal mucosa of patients with postinfectious functional dyspepsia. Am J Gastroenterol 2010;105:1835-1842.

69. Tack J, Demedts I, Dehondt G, et al. Clinical and pathophysiological characteristics of acute-onset functional dyspepsia. Gastroenterology 2002;122:1738-1747.

70. Dizdar V, Spiller R, Singh G, et al. Relative importance of abnormalities of CCK and 5-HT (serotonin) in Giardia-induced postinfectious irritable bowel syndrome and functional dyspepsia. Aliment Pharmacol Ther 2010;31:883-891.

71. Spiller R. Postinfectious functional dyspepsia and postinfectious irritable bowel syndrome: different symptoms but similar risk factors. Gastroenterology 2010;138:1660-1663.

72. Talley NJ, Locke GR, Lahr BD, et al. Predictors of the placebo response in functional dyspepsia. Aliment Pharmacol Ther 2006;23:923-936.

73. Pilichiewicz AN, Horowitz M, Holtmann GJ, Talley NJ, FeinleBisset C. Relationship between symptoms and dietary patterns in patients with functional dyspepsia. Clin Gastroenterol Hepatol 2009;7:317-322

74. Zala AV, Walker MM, Talley NJ. Emerging drugs for functional 
dyspepsia. Expert Opin Emerg Drugs 2015;20:221-233.

75. Moshiree B, Barboza J, Talley N. An update on current pharmacotherapy options for dyspepsia. Expert Opin Pharmacother 2013;14:1737-1753.

76. Lacy BE, Talley NJ, Locke GR 3rd, et al. Review article: current treatment options and management of functional dyspepsia. Aliment Pharmacol Ther 2012;36:3-15.

77. Yazdanbod A, Salimian S, Habibzadeh S, Hooshyar A, Maleki N, Norouzvand M. Effect of Helicobacter pylori eradication in Iranian patients with functional dyspepsia: a prospective, randomized, placebo-controlled trial. Arch Med Sci 2015;11:964-969.

78. Mazzoleni LE, Sander GB, Francesconi CF, et al. Helicobacter pylori eradication in functional dyspepsia: HEROES trial. Arch Intern Med 2011;171:1929-1936.

79. Talley NJ, Vakil NB, Moayyedi P. American gastroenterological association technical review on the evaluation of dyspepsia. Gastroenterology 2005;129:1756-1780.

80. Sugano K, Tack J, Kuipers EJ, et al. Kyoto global consensus report on Helicobacter pylori gastritis. Gut 2015;64:1353-1367.

81. Holtmann G, Talley NJ. Functional dyspepsia. Curr Opin Gastroenterol 2015;31:492-498.

82. Moayyedi P, Delaney BC, Vakil N, Forman D, Talley NJ. The efficacy of proton pump inhibitors in nonulcer dyspepsia: a systematic review and economic analysis. Gastroenterology 2004;127:1329-1337.

83. Talley NJ, Vakil N, Lauritsen K, et al. Randomized-controlled trial of esomeprazole in functional dyspepsia patients with epigastric pain or burning: does a 1-week trial of acid suppression predict symptom response? Aliment Pharmacol Ther 2007;26:673-682.

84. Friesen CA, Sandridge L, Andre L, Roberts CC, Abdel-Rahman SM. Mucosal eosinophilia and response to $\mathrm{H} 1 / \mathrm{H} 2$ antagonist and cromolyn therapy in pediatric dyspepsia. Clin Pediatr (Phila) 2006;45:143-147.

85. Molina-Infante J, Rivas MD, Hernandez-Alonso M, et al. Proton pump inhibitor-responsive oesophageal eosinophilia correlates with downregulation of eotaxin-3 and Th2 cytokines overexpression. Aliment Pharmacol Ther 2014;40:955-965.

86. Hondeghem LM. Domperidone: limited benefits with significant risk for sudden cardiac death. J Cardiovasc Pharmacol 2013;61:218-225.

87. Talley NJ, Tack J, Ptak T, Gupta R, Giguère M. Itopride in functional dyspepsia: results of two phase III multicentre, randomised, double-blind, placebo-controlled trials. Gut 2008;57:740-746.

88. Huang X, Lv B, Zhang S, Fan YH, Meng LN. Itopride therapy for functional dyspepsia: a meta-analysis. World J Gastroenterol 2012;18:7371-7377.

89. Holtmann G, Talley NJ, Liebregts T, Adam B, Parow C. A placebo-controlled trial of itopride in functional dyspepsia. N Engl J
Med 2006;354:832-840.

90. Amano T, Ariga H, Kurematsu A, et al. Effect of 5-hydroxytryptamine receptor 4 agonist mosapride on human gastric accommodation. Neurogastroenterol Motil 2015;27:1303-1309.

91. Bang CS, Kim JH, Baik GH, et al. Mosapride treatment for functional dyspepsia: a meta-analysis. J Gastroenterol Hepatol 2015;30:28-42.

92. Matsueda K, Hongo M, Tack J, Saito Y, Kato H. A placebocontrolled trial of acotiamide for meal-related symptoms of functional dyspepsia. Gut 2012;61:821-828.

93. Xiao G, Xie X, Fan J, Deng J, Tan S, Zhu Y, Guo Q, Wan C. Efficacy and safety of acotiamide for the treatment of functional dyspepsia: systematic review and meta-analysis. ScientificWorldJournal 2014;2014:541950.

94. Tack J, Janssen P, Masaoka T, Farré R, Van Oudenhove L. Efficacy of buspirone, a fundus-relaxing drug, in patients with functional dyspepsia. Clin Gastroenterol Hepatol 2012;10:1239-1245.

95. Talley NJ, Locke GR, Saito YA, et al. Effect of amitriptyline and escitalopram on functional dyspepsia: a multicenter, randomized controlled study. Gastroenterology 2015;149:340-349.e2.

96. Ford AC, Luthra P, Tack J, Boeckxstaens GE, Moayyedi P, Talley NJ. Efficacy of psychotropic drugs in functional dyspepsia: systematic review and meta-analysis. Gut. Epub 2015 Nov 13. https://doi.org/10.1136/gutjnl-2015-310721.

97. Tack J, Ly HG, Carbone F, et al. Efficacy of mirtazapine in patients with functional dyspepsia and weight loss. Clin Gastroenterol Hepatol 2016;14:385-392.e4.

98. Friesen CA, Kearns GL, Andre L, Neustrom M, Roberts CC, AbdelRahman SM. Clinical efficacy and pharmacokinetics of montelukast in dyspeptic children with duodenal eosinophilia. J Pediatr Gastroenterol Nutr 2004;38:343-351.

99. Pilichiewicz AN, Horowitz M, Russo A, et al. Effects of Iberogast on proximal gastric volume, antropyloroduodenal motility and gastric emptying in healthy men. Am J Gastroenterol 2007;102:1276-1283.

100. Holtmann G, Talley NJ. Herbal medicines for the treatment of functional and inflammatory bowel disorders. Clin Gastroenterol Hepatol 2015;13:422-432.

101. Kim KN, Chung SY, Cho SH. Efficacy of acupuncture treatment for functional dyspepsia: a systematic review and meta-analysis. Complement Ther Med 2015;23:759-766.

102. Haag S, Senf W, Tagay S, et al. Is there a benefit from intensified medical and psychological interventions in patients with functional dyspepsia not responding to conventional therapy? Aliment Pharmacol Ther 2007;25:973-986.

103. Ford AC, Forman D, Bailey AG, Axon AT, Moayyedi P. Effect of dyspepsia on survival: a longitudinal 10-year follow-up study. Am J Gastroenterol 2012;107:912-921. 